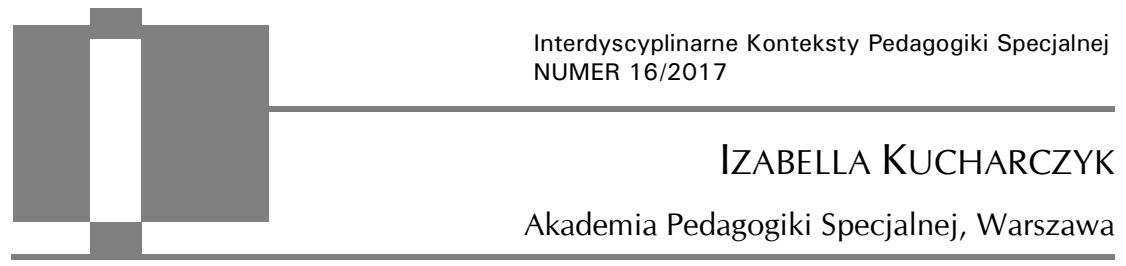

\title{
Recenzja książki pod redakcją Lidii Cierpiałkowskiej i Heleny Sęk pt. Psychologia kliniczna, Wydawnictwo PWN, Warszawa 2016, s. 855
}

Książka ta to pierwsze na polskim rynku wydawniczym tak obszerne opracowanie zagadnień poświęconych psychologii klinicznej, uwzględniające co najmniej kilkanaście różnych problemów. Recenzowana publikacja składa się sześciu części, a każda z nich poświęcona jest innemu zagadnieniu. Publikacja rozpoczyna się od wstępu, a kończy załącznikami, bibliografią, indeksem nazwisk, indeksem rzeczowym i informacjach o autorach, którzy napisali poszczególne rozdziały. Jest to publikacja opracowana w bardzo przejrzysty sposób. Każdy rozdział rozpoczyna się czytelnym spisem treści, a kończy krótkim podsumowaniem oraz spisem podstawowych pojęć i literaturą zalecaną. Warto również zaznaczyć, że w każdym rozdziale, oprócz treści podstawowych, zaprezentowano bloki rozszerzające, w których opisywane są interesujące badania i eksperymenty związane $\mathrm{z}$ danym tematem.

Część pierwsza (rozdziały 1-5.) poświęcona została ogólnym zagadnieniom psychologii klinicznej. W rozdziale pierwszym, zatytułowanym „Psychologia kliniczna jako dziedzina badań i praktyki” opracowanym przez Lidię Cierpiałkowską oraz Helenę Sęk syntetycznie przedstawiono zarys historyczny powstawania myśli psychologicznej. W kolejnych rozdziałach (2-4.; opracowanie: L. Cierpiałkowska, H. Sęk) wydzielono również psychologię $\mathrm{z}$ innych nauk, opisano pojęcie normy, normalności i zdrowia, a także podjęto problem psychologii klinicznej i psychopatologii. Dokonując prezentacji zaburzeń psychicznych, autorka nie tylko opisuje pojęcie, ale także nawiązuje do Międzynarodowej Klasyfikacji Chorób i Problemów Zdrowotnych ICD-10 oraz odwołuje się do klasyfikacji 
ICD-11. Bardzo przydatne dla czytelnika może być również ujęcie zaburzeń psychicznych w klasyfikacji DSM V, a także odniesienie do Międzynarodowej Klasyfikacji Funkcjonowania, Niepełnosprawności i Zdrowia. W piątym rozdziale pt. „Etyka postępowania psychologa klinicznego w badaniach naukowych i praktyce" autor (Jerzy Marian Brzeziński) zwraca uwagę na bardzo ważki problem, o którym każdy psycholog powinien pamiętać, prowadząc zarówno badania naukowe, jak i terapię, czyli na aspekt etyczny. Treści w całej części pierwszej zostały przedstawione tekstów, tabel i schematów.

Część II pt. „Kierunki i podejścia w psychologii klinicznej” obejmuje takie zagadnienia jak: współczesna psychoanaliza i jej znaczenie dla psychologii klinicznej (rozdział 6.), kierunki behawioralne i podejście poznawcze w psychologii klinicznej (rozdział 7.), podejście fenomenologiczne, egzystencjalne i humanistyczne w psychologii klinicznej (rozdział 8.) i koncepcje systemowe i ich znaczenie dla psychologii klinicznej (rozdział 9.).

W rozdziale szóstym, pt. „Współczesna psychoanaliza i jej znaczenie dla psychologii klinicznej" L. Cierpiałkowska rozpoczęła rozważania od wyjaśnienia, czym jest psychoanaliza Zygmunta Freuda. Zaprezentowała główne idee psychoanalizy (pojęcie popędu, podział osobowości, mechanizmy obronne, które zdaniem Freuda człowiek stosuje w swym życiu). Zwróciła też uwagę na powstawanie nerwic i perseweracji seksualnych. W rozdziale tym autorka podejmuje również wątek okresu preedypalnego $\mathrm{w}$ teorii relacji z obiektem i psychologii self. Bardzo wartościowym dla czytelnika może być zaprezentowanie wiedzy na temat współczesnej psychoanalizy i porównanie jej z innymi koncepcjami psychodynamicznymi, a także wyjaśnienie, w jaki sposób powstają zaburzenia osobowości i psychozy $\mathrm{w}$ oparciu o teorię relacji $\mathrm{z}$ obiektem. Trzecim aspektem podjętym $\mathrm{w}$ rozdziale 6. jest zagadnienie psychologii defektu i fałszywego self.

Następny rozdział (7.; autorki: Dominika Górska, Aleksandra Jasielska) odnosi się do zagadnień związanych z dwoma kierunkami w psychologii, tj. z podejściem behawioralnym i podejściem poznawczym. Autorki wychodzą od prezentacji nurtu behawiorystycznego. Prezentują, czym jest warunkowanie klasyczne, instrumentalne, ale też zwracają uwagę na różne sposoby na różne sposoby manipulacji zachowaniem. Dość szeroko opisują m.in. teorię społecznego uczenia się Alberta Bandury, a także techniki behawioralne wykorzystywane $\mathrm{w}$ procesie pomocy psychologicznej i terapii zaburzeń psychicznych. Kolejny poruszony aspekt to omówienie podejścia poznawczego i jego podstawowych założeń. Oprócz przedstawienia naj- 
ważniejszych pojęć, autorki tłumaczą, w jaki sposób powstaje zaburzenie, jakie są modele poznawcze zaburzeń psychicznych i jakie mechanizmy je podtrzymują. Bardzo wartościowe jest zwrócenie uwagi na nowe kierunki dominujące $\mathrm{w}$ podejściu poznawczo-behawioralnym tj. teorię biospołeczną zaburzeń osobowości borderline Marshy M. Linehan, teoria schematów Younga.

Przedostatni rozdział, dziewiąty, pierwszej części autorstwa H. Sęk dotyczy podejścia fenomenologicznego, egzystencjalnego i humanistycznego w psychologii. Autorka opisuje znaczenie tych trzech nurtów, przedstawiając wszystkie za i przeciw tym podejściom. Zwrócono uwagę na rozbudowane koncepcje charakteryzujące osobowość człowieka, podejście do diagnozy jak i terapii.

Ostatni rozdział tej części (10; autorka: Barbara Józefik) prezentuje koncepcje systemowe $\mathrm{w}$ podejściu do rodziny $\mathrm{i}$ ich zastosowanie $\mathrm{w}$ psychologii klinicznej. Autorka przedstawia etapy rozwoju systemowego, poszczególne zasady dotyczące funkcjonowania rodziny jako systemu, którzy ciągle się zmienia i ewoluuje, a także w bardzo klarowny sposób cykl życia rodziny. Autorka opisała również różne współczesne modele rodziny: model systemów Murraya. Bowena, koncepcja Ivana Boszormenyi-Nagya, koncepcja wiązania i delegowania Helma Stierlina. Dodatkowym uzupełnieniem jest prezentacja koncepcji ahistorycznych wyjaśniających funkcjonowanie rodziny tj. model interakcyjno-komunikacyjny, model strategiczny i model strukturalny. H. Sęk podejmuje problem podejścia narracyjnego w terapii rodzin, które jest dość popularne w ostatnich dwóch dekadach.

Część III, pt. „Psychologiczna diagnoza kliniczna”, jest niezwykle istotnym zagadnieniem podjętym $\mathrm{w}$ tej publikacji, gdyż na niej opiera się cały proces terapeutyczny. Część ta składa się z czterech rozdziałów. Rozdział 10. („Modele diagnozy klinicznej a problemy diagnostyczne”; autorki: Lidia Cierpiałkowska, Emilia Soroko, Hanna Sęk) przedstawiony został $\mathrm{w}$ tabelaryczny, schematyczny sposób, z szeroko rozwiniętymi blokami rozszerzającymi. Autorki dokonały bardzo interesującego przedstawienia treści, które prezentuje rodzaje diagnozy takie jak: diagnoza całościowa, wybiórcza, epigenetyczna, rozwojowa, nozologiczna, psychologiczna, strukturalno-funkcjonalna. Bardzo interesująca wydaje się być prezentacja sekwencji postepowania diagnostycznego i terapeutycznego $\mathrm{w}$ procesie psychoterapii (rozdział 11.; autorki: L. Cierpiałkowska, E. Soroko, H. Sęk).

Kolejnym poruszonym zagadnieniem związanym z diagnozą są metody stosowane w psychologicznej diagnozie klinicznej (12; autorka: E. Soro- 
ko). Rozdział ten został zaprezentowany w taki sposób, że powinien być obowiązkowym artykułem dla studentów rozpoczynających studia $\mathrm{w}$ zakresie psychologii. Autorki podzieliły metody na cztery podstawowe grupy. Wyróżniły: rozmowę i obserwację, metody kwestionariuszowe, metody badania procesów poznawczych oraz bardzo trudne $\mathrm{w}$ interpretacji w praktyce klinicznej metody projekcyjne.

Ostatnim rozdziałem (13.; autorki: L. Cierpiałkowska, E. Soroko) w części trzeciej jest rozdział dotyczący jakości diagnozy klinicznej. Rozdział ten został podzielony na trzy części. Pierwsza odnosi się do omówienia roli diagnozowania opartego na dowodach. Druga - prezentuje treści dotyczące uwarunkowań w procesie diagnostycznym, czyli czynników związanych z pacjentem i samym diagnostą. Trzecia - standardów, jakie powinny być spełnione $\mathrm{w}$ diagnozie, aby zapobiec błędom i występowaniu różnych artefaktów. Autorki podjęły przy tym problem celów, jakie powinny przyświecać $\mathrm{w}$ procesie kształcenia przyszłych klinicystów.

Część IV została poświęcona psychologii zaburzeń psychicznych człowieka dorosłego, dlatego znajomość poszczególnych zaburzeń i dysfunkcji w procesie diagnostycznym jest bardzo ważna. W rozdziale 14., pt. „Psychologia zaburzeń osobowości" (autorki: L. Cierpiałkowska, D. Górska) skupiono się na opisaniu zaburzeń osobowości w modelach opisowych. Wartościowym wydaje się być scharakteryzowanie współczesnych podejść, zwłaszcza psychoanalizy, podejścia poznawczego, integracyjnego, koncepcji bio-psycho-społecznych i ewolucyjnej do zaburzeń osobowości. Podsumowaniem tego podrozdziału jest zwrócenie uwagi na współczesne badania prowadzone nad efektywnością psychoterapii w leczeniu osób z zaburzeniami osobowości.

Kolejny rozdział, 15. („Psychologia zaburzeń lękowych i dysocjacyjnych"; autorki: L. Cierpiałkowska, D. Górska) opisuje zaburzenia, które zaczynają pojawiać się coraz częściej u współczesnych pacjentów. Autorki rozpoczęły od przedstawienia kryteriów diagnostycznych wg najnowszych klasyfikacji: ICD-10 i DSM-V, a także, jak w poprzednim rozdziale, wskazały, w jaki sposób diagnozuje i terapeutyzuje się pacjenta zgodnie $\mathrm{z}$ nurtem behawioralnym, poznawczym, psychoanalitycznym.

Rozdział szesnasty dotyczy bardzo trudnego do diagnozy i terapii zaburzenia psychicznego, a mianowicie schizofrenii (autorki: Helena Sęk, Stanisława Steuden). Autorki rozpoczęły od przedstawienia symptomatologii schizofrenii, a następnie scharakteryzowały poszczególne jej rodzaje. Wart szczegółowego przeczytania jest podrozdział, w którym autorki opi- 
sują psychologiczne badania eksperymentalne $\mathrm{w}$ schizofrenii, koncepcje wyjaśniające powstawanie tego zaburzenia psychicznego, a także sposób doświadczania zaburzeń schizofrenicznych. Na końcu autorki omówiły, jakie są psychospołeczne konsekwencje schizofrenii z punktu widzenia pacjenta.

Rozdział 17. poświęcony został psychologii zaburzeń nastroju (autorka: H. Sęk). Zaburzenia afektywne należą do jednym z częstszych zaburzeń o podłożu społecznym. Cechą typową jest ich zróżnicowana symptomatologia, różnorodny przebieg i różne patomechanizmy powstawania. Najbardziej typowe to manie, hipomanie, depresje. $\mathrm{Z}$ zespołami maniakalno-depresyjnymi mogą być związane zespoły stresu pourazowego (PTSD), które opisano w rozdziale 18. (autorka: L. Cierpiałkowska). Omówiono pojęcie traumy, konsekwencje, ale także mechanizmy powstawania wraz koncepcjami. Uwzględniono również dane dotyczące sposobu terapii osób z PTSD.

W XXI w. i dobie problemów dotyczących m.in. negatywnych skutków dopalaczy, alkoholu, substancji narkotycznych rozdział dziewiętnasty poświęcono psychologii uzależnień. Jest to rozdział, w którym czytelnik może zaznajomić się z typami środków uzależniających, zespołami i zaburzeniami związanymi ze spożywaniem tychże substancji. W interesujący sposób zaprezentowano skutki zespołów odstawiennych, a także bardzo przejrzyście scharakteryzowano za pomocą rycin modele uzależnienia od środków psychoaktywnych, w tym alkoholu. Warto zapoznać się z zaburzeniami związanymi $\mathrm{z}$ grami internetowymi przedstawionymi $\mathrm{w}$ bloku rozszerzającym. Jako ostatnie zagadnienie omówiono efektywność programów leczenia w świetle najnowszych badań.

Dwa ostatnie rozdziały trzeciej części odnoszą się do chorób cywilizacyjnych: zaburzeń odżywiania (rozdział 20.) i zaburzeń seksualnych (rozdział 21.).

Przedostatnia część - V, pt. „Dziedziny zastosowań psychologii klinicznej" dotyczy problemów diagnostyczno-terapeutycznych występujących w różnych obszarach.

Rozdział 22. "Psychologia kliniczna dzieci i młodzieży” autorstwa Iwony Grzegorzewskiej, Ewy Pisuli i Anety Borkowskiej zawiera treści, które powinien znać każdy psycholog praktyk, zarówno diagnosta, jak i terapeuta. Podrozdział pierwszy ma charakter ogólny i opisuje specyfikę zaburzeń okresu dzieciństwa i adolescencji. Wartościowe np. dla studentów czy początkowych diagnostów mogą być zestawienia różnych ogólnych problemów w formie tabelarycznej i schematycznej. Bardzo szczegó- 
łowo opisano zaburzenia emocjonalne i behawioralne występujące $\mathrm{u}$ dzieci: sposób ich powstawania, symptomatologię oraz skutki. Uzupełnieniem jest zwrócenie uwagi na problemy dziecka w sytuacji trudnej (w sytuacji rozwodu rodziców, gdy rodzice mają chorobę psychiczną). Wiele miejsca $\mathrm{w}$ tym rozdziale poświęcono całościowym zaburzeniom rozwoju. Oprócz podstawowych informacji na temat definicji, klasyfikacji i etiologii, autorki bardzo szczegółowo scharakteryzowały obraz kliniczny tych zaburzeń oraz dokonały prezentacji danych dotyczących diagnozy i terapii autyzmu, krótkiego opisu najnowszych metod wykorzystywanych w diagnozie psychologicznej i zasad dobrej interwencji wobec osób z zaburzeniami ze spektrum autyzmu. Nie zabrakło również informacji na temat problemów, jakie mogą się pojawić $\mathrm{w}$ rodzinie dziecka z autyzmem. Należy podkreślić, że monografii na temat neuropsychologii dzieci i młodzieży jest na rynku polskim stosunkowo niewiele. Dlatego też autorki wiele miejsca $\mathrm{w}$ tym rozdziale poświęciły na opracowanie zagadnień dotyczących zaburzeń neurorozwojowych. Dokonały porównania między neuropsychologią dorosłych oraz dzieci i młodzieży, a także opisały najbardziej typowe zaburzenia dziecięce jak: ADHD, FASD, zespoły genetyczne, nabyte zmiany strukturalne i funkcjonalne OUN dzieci i młodzieży. Zakończenie tego rozdziału to opis celów i zadań, jakie są stawiane w procesie neuropsychologicznej diagnozy dziecka, a także określenie kierunków terapii neuropsychologicznej dzieci i młodzieży.

W rozdziale 23., „Neuropsychologia kliniczna jako dziedzina badań i praktyki", Anna Herzyk omawia najważniejsze problemy neuropsychologii klinicznej. Przedstawia przedmiot i zakres badań, ewolucję poglądów. Niebagatelne jest zaprezentowanie uwarunkowań patologii mózgu, ze zwróceniem uwagi na rodzaje deficytów neuropsychologicznych. Autorka zwraca też uwagę na postępowanie diagnostyczne i podejmowane oddziaływania terapeutyczne $\mathrm{w}$ neuropsychologii.

Rozdział 24. poświęcony został psychologii zdrowia (autorka: Irena Heszen). Autorka rozdziału sporo uwagi poświęca wyjaśnieniu paradygmatu Lazarusa i Folkmana i pojęciu stresu i podkreśla, że czynniki stresogenne działają na każdą jednostkę, a sposób poradzenia sobie z nimi może determinować pojawienie się różnych chorób.

Następny rozdział odnosi się do zagadnień związanych z psychologią niepełnosprawności i rehabilitacji psychologicznej. Stanisław Kowalik nie tylko wyjaśnia, czym jest niepełnosprawność, ale zwraca uwagę na psychologiczne konsekwencje niepełnosprawności i rehabilitacji. 
Przedostatni rozdział tej części pt. „Psychologia kliniczna seniorów” (26., autorka: S. Steuden) to rozdział opisujący jedną z subdyscyplin psychologii klinicznej. Proces starzenia się i starość jest aktualnie coraz częściej omawiana w literaturze przedmiotu. Coraz więcej naukowców zawraca uwagę na sposób funkcjonowania na tym etapie życia. Niebagatelne jest podjęcie takiego problemu jak doświadczanie starości przez osoby starsze, w tym ich przystosowanie do starości, mądrość życiowa, bilans życiowy, a także postawy wobec własnej starości. Na koniec przedstawione są informacje dotyczące roli i zadań osób starszych w rodzinie.

Ostatni rozdział (27., autorzy: Beata Pastwa-Wojciechowska, Jarosław Groth) to problematyka psychologii sądowej. Rozdział ten zawiera wiele praktycznych wskazówek dotyczących wykorzystywania klinicznej psychologii sądowej. Przenalizowano zadania psychologów jako biegłych, opiniodawstwo sądowo-psychologiczne oraz kryteria wiarygodności ekspertyzy sądowej, z zaakcentowaniem problemów diagnozy sądowo-psychologicznej. Rozdział ten zakończono opisaniem etyczno-zawodowych problemów biegłego i psychologa sądowego.

Ostatnia część, VI, pt. „Typy pomocy psychologicznej w rozwiązywaniu problemów zdrowotny” składa się z siedmiu rozdziałów: „Psychoterapia indywidualna i grupowa” (rozdział 28.), "Poradnictwo psychologiczno-zdrowotne” (rozdział 29.), "Promocja zdrowia i prewencja zaburzen" (rozdział 30.), "Pomoc psychologiczna w różnych typach kryzysu” (rozdział 31.), „Społeczna rehabilitacja zaburzeń psychicznych. Środowiskowe metody pomocy osobom z doświadczeniem choroby psychicznej" (rozdział 32.), "Grupy samopomocy a społeczność terapeutyczna” (rozdział 33.), „Efektywność poradnictwa psychologicznego i psychoterapii” (rozdział 34.). Wszystkie te rozdziały dotyczą przede wszystkim pomocy $\mathrm{w}$ procesie poradnictwa w szerokim rozumieniu.

Publikacja pod redakcją Lidii Cierpiałkowskiej i Heleny Sęk pt. Psychologia kliniczna jest jedną z ważniejszych publikacji na rynku wydawniczym. Wartość omawianej monografii polega na tym, że może ona stanowić kompendium wiedzy nie tylko na naukowców, psychologów praktyków diagnostów i terapeutów, ale także dla studentów różnych kierunków studiów. Uwzględnia najnowsze badania i wiedzę dotyczącą psychologii klinicznej. 